\title{
Stable Attachment of $\mathrm{TiB}_{2}$-Based Cathodes for the Aluminum Industry: Review and Recommendation
}

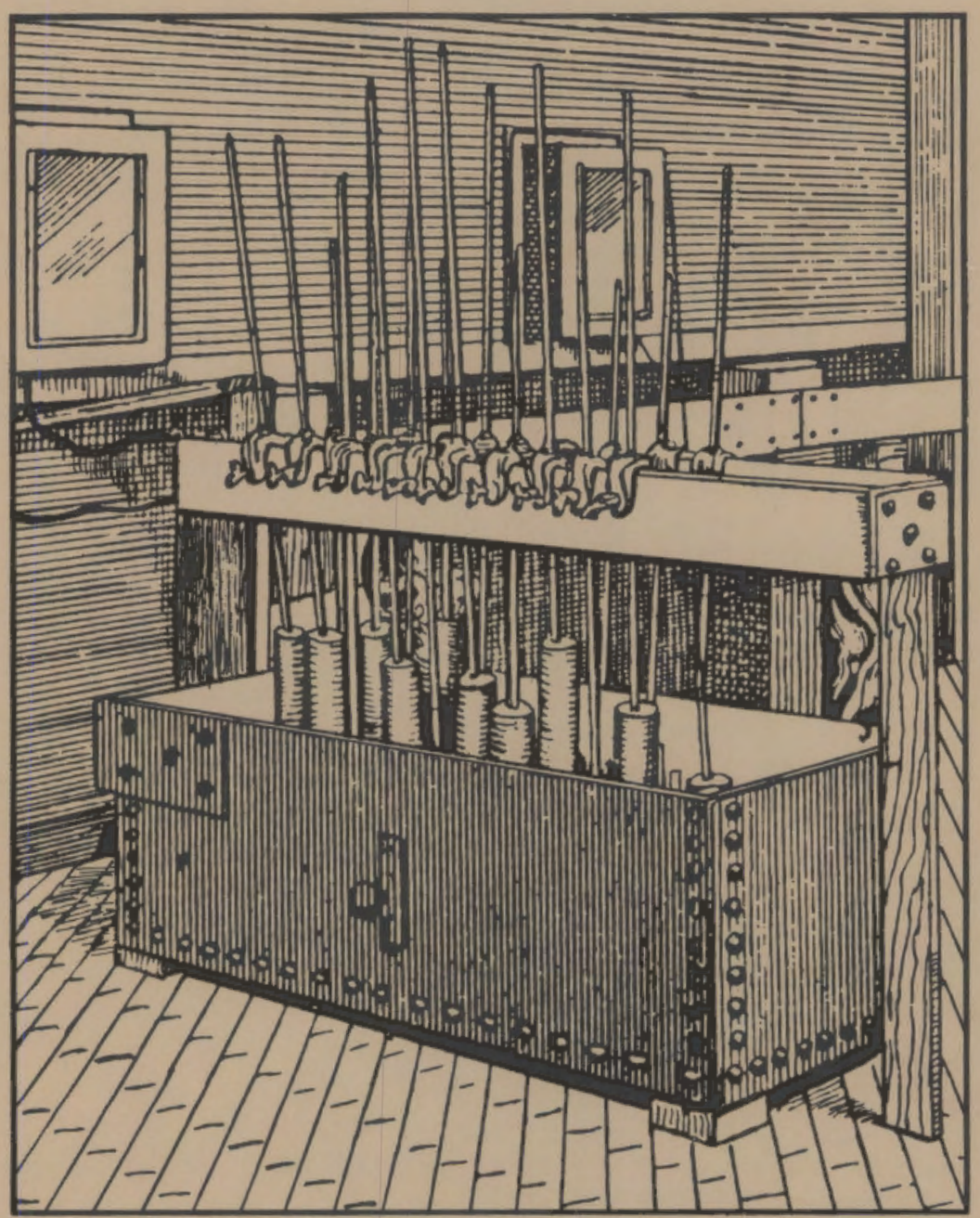

May 1987

Work Supported by the U.S. Department of Energy under Contract DE-AC06-76RLO 1830

Pacific Northwest Laboratory Operated for the U.S. Department of Energy by Battelle Memorial Institute 


\title{
On the cover:
}

\section{Aluminum reduction pots at the Pittsburgh Reduction Company's (Alcoa's) plant in 1889. Adapted from a photograph, courtesy of Alcoa.}

\begin{abstract}
DISCLAIMER
This report was prepared as an account of work sponsored by an agency of the United States Government. Neither the United States Government nor any agency thereof, nor Battelie Memorial Institute, nor any of their employees, makes any warranty, expressed or implied, or assumes any legal liability or responsibility for the accuracy, completeness, or usefulness of any information, apparatus, product, or process disclosed, or represents that its use would not infringe privately owned rights. Reference herein to any specific commercial product, process, or service by trade name, trademark, manufacturer, or otherwise, does not necessarily constitute or imply its endorsement, recommendation, or favoring by the United States Government of any agency thereof, or Battelle Memorial Institute. The views and opinions of authors expressed herein do not necessarly state or reflect those of the United States Government or any agency thereof, or Battelle Memorial Institute.
\end{abstract}

\section{PACIFIC NORTHWEST LABORATORY operated by \\ BATTELLE MEMORIAL INSTITUTE for the \\ UNITED STATES DEPARTMENT OF ENERGY under Contract DE-AC06-76RLO 1830}

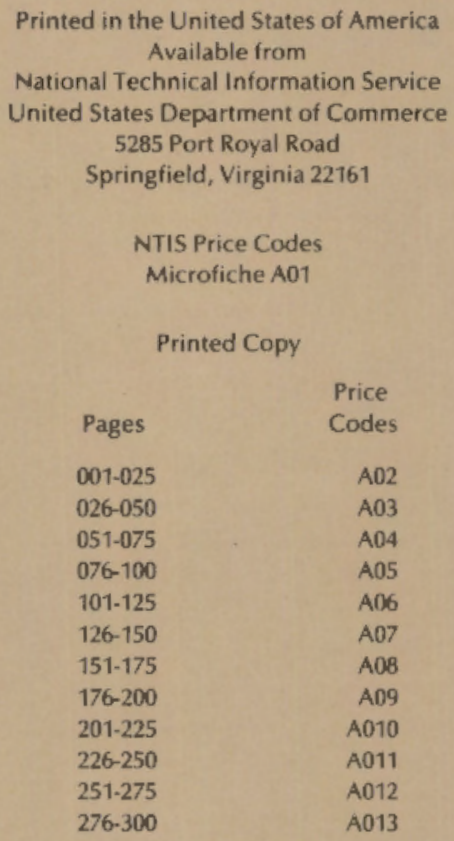


STABLE ATTACHMENT OF TiB 2 -BASED

CATHODES FOR THE ALUMINUM INDUSTRY:

REVIEW AND RECOMMENDATION

C. H. Schilling

D. I. Hagen

P. E. Hart

May 1987

Prepared for the

U.S. Department of Energy

under Contract DE-AC06-76RLO 1830

Pacific Northwest Laboratory

Richland, Washington 99352 


\section{ABSTRACT}

This report summarizes the results of a literature review of methods for applying $\mathrm{TiB}_{2}$-based cathode materials to the Hall-Heroult process used for the commercial production of aluminum. The report discusses applicable patents, alternative bonding and coating techniques, and developmental research performed by several aluminum companies. Recommendations are given for future directions in refrofitting Hall-Heroult cells with stable $\mathrm{TiB}_{2}$-based cathode materials. 
<smiles>[Mg][Mg]</smiles> 


\section{CONTENTS}

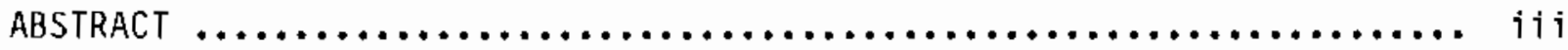

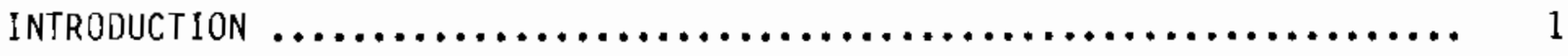

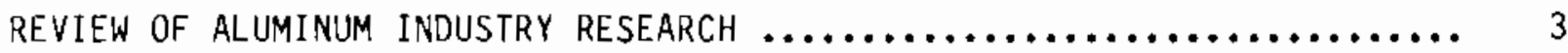

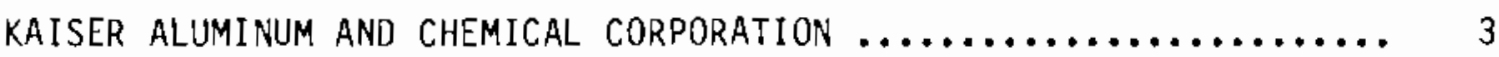

MARTIN MARIETTA/COMMONWEALTH ALUMINUM CORPORATION $\ldots \ldots \ldots \ldots \ldots . . . \ldots$

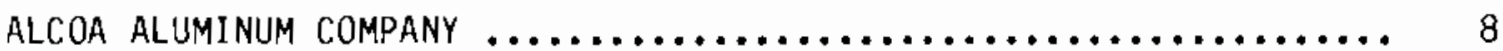

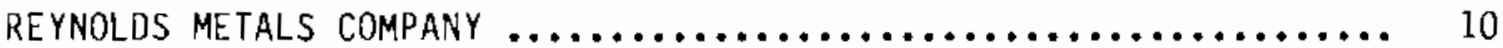

ADDITIONAL APPLICABLE DATA $\ldots \ldots \ldots \ldots \ldots \ldots \ldots \ldots \ldots \ldots \ldots \ldots, 12$

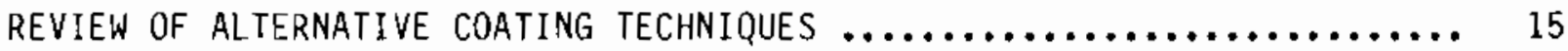

CHEMICAL VAPOR DEPOSITION $\ldots \ldots \ldots \ldots \ldots \ldots \ldots \ldots \ldots \ldots \ldots \ldots \ldots, 15$

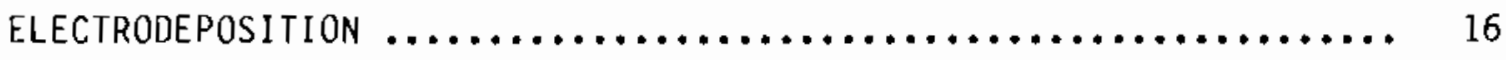

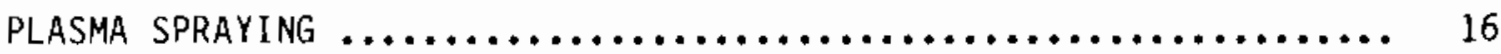

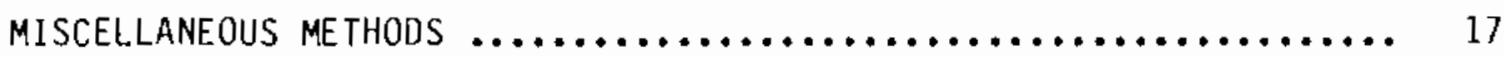

RECOMMENDATIONS FOR RETROFITTING HALL CELLS $\ldots \ldots \ldots \ldots \ldots \ldots \ldots \ldots \ldots, 21$

WEAR-RESISTANT MATERIALS SELECTION $\ldots \ldots \ldots \ldots \ldots \ldots \ldots \ldots \ldots \ldots, 21$

ATTACHING $\mathrm{TiB}_{2}$-BASED ARTICLES TO CARBONACEOUS CELL FLOORS $\ldots \ldots \ldots . .23$

Cements $\ldots \ldots \ldots \ldots \ldots \ldots \ldots \ldots \ldots \ldots \ldots \ldots \ldots \ldots \ldots, 23$

$\mathrm{TiB}_{2}$-Carbon Pastes $(\mathrm{TiBCM}) \ldots \ldots \ldots \ldots \ldots \ldots \ldots \ldots \ldots \ldots \ldots \ldots \ldots \ldots \ldots \ldots, 24$

$\mathrm{TiB}_{2}-\mathrm{A} 1 \mathrm{~N}$ Hot Pressed to Graphite $\ldots \ldots \ldots \ldots \ldots \ldots \ldots \ldots \ldots . . . \ldots \ldots$

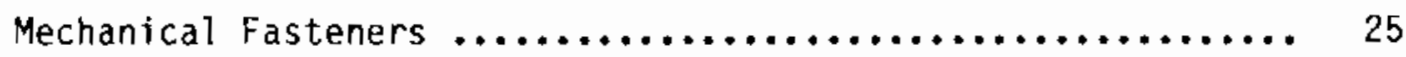

REPLACEABLE CATHODE FIXTURES $\ldots \ldots \ldots \ldots \ldots \ldots \ldots \ldots \ldots \ldots \ldots \ldots, 25$

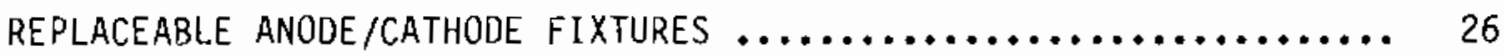

PACKED BED CATHODES $\ldots \ldots \ldots \ldots \ldots \ldots \ldots \ldots \ldots \ldots \ldots \ldots \ldots \ldots \ldots, 26$ 
Miscellaneous $\mathrm{TiB}_{2}$ coating processes $\ldots \ldots \ldots \ldots \ldots \ldots \ldots \ldots \ldots \ldots \ldots \ldots$

Chemical Vapor Deposition $\ldots \ldots \ldots \ldots \ldots \ldots \ldots \ldots \ldots \ldots \ldots \ldots \ldots$

Electrodeposition $\ldots \ldots \ldots \ldots \ldots \ldots \ldots \ldots \ldots \ldots \ldots \ldots \ldots \ldots \ldots \ldots$

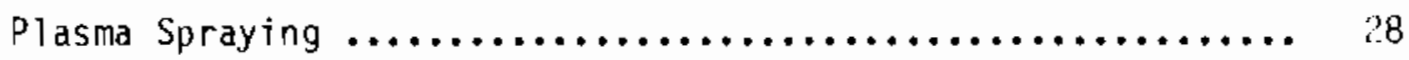

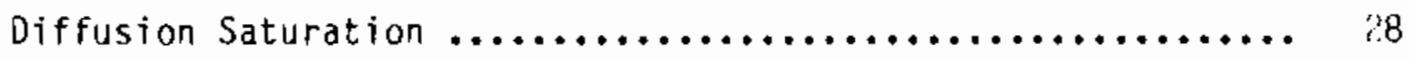

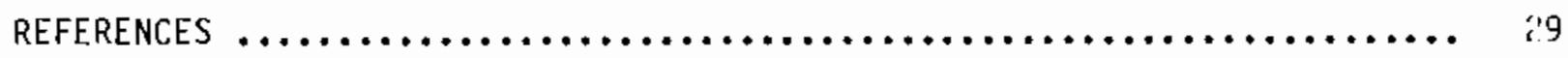




\section{INTRODUCTION}

The Inert Anode/Cathode Program is conducted by Pacific Northwest Laboratory for the U.S. Department of Energy (DOE), Office of Industrial Programs (0IP). The purpose of the program is to develop long-lasting, energy-efficient anodes, cathodes, and ancillary equipment for Hall-Heroult cells used for the commercial production of aluminum. The program is divided into four tasks:

- Inert Anode Development - to improve the overall energy efficiency of the Hall-Heroult process by development of inert anodes.

- Cathode Materials Evaluation - to confirm the chemical behavior of carbon-containing $\mathrm{TiB}_{2}$ cathode material ( $\mathrm{TiBCM}$ ) in the presence of molten cryolite and aluminum, and to upgrade the analytical procedures for $\mathrm{AT}_{4} \mathrm{C}_{3}$ in cryolite.

- Stable Cathode Studies - to develop methods for retrofitting HallHeroult cells with $\mathrm{TiB}_{2}$-based cathode materials.

- Sensor Development - to devise sensors to control the chemistry of Hall-Heroult cells using stable anodes and cathodes.

This report is one of several that are being issued by PNL to document activities sponsored by the DOE OIP. The focus of this report is twofold: 1) to review research efforts in the development of stable $\mathrm{TiB}_{2}$-based cathode materials and their bonding methods for Hall-Heroult cell retrofit applications, and 2) to recommend future directions for retrofitting commercial cells based on this review.

Refractory hard materials, in particular $\mathrm{TiB}_{2}$, have long been considered for cathodes in industrial Hall-Heroult cells. (a) The advantages of TiB 2 -based cathode materials mainly consist of their ability to be wetted by molten aluminum, thereby enabling a reduction in the anode-to-cathode spacing with a consequent savings in energy usage.

(a) Beck 1982; Todd 1981; Ransley 1962 and 1963; Grjotheim et al. 1982; and an extensive literature review by Billehaug and Oye 1980. 
One of the major problems that has impeded the use of refractory hard materials in industrial cells is the difficulty in forming a stable, adherent bond with the cell liner material. Other problems include the cost of the refractory hard materials and their susceptibility to breakage under normal handling and cell operating procedures. Until these difficulties are resoived, these materials will not be used in industrial cells for cathode applications. 


\section{REVIEW OF ALUMINUM INDUSTRY RESEARCH}

Aluminum industry research directly related to the attachment of $\mathrm{TiB}_{2}-$ based materials to hall-Heroult cells will be discussed in this section.

\section{KAISER ALUMINUM AND CHEMICAL CORPORATION}

From 1956 to 1964, efforts at Kaiser Aluminum and Chemical Corporation (KACC) were made to form cathode materials from the then-available $\mathrm{TiB}_{2}$ powders. At that time, the oxygen content of the $\mathrm{TiB}_{2}$ powders was too high to produce sintered materials that could resist intergranular penetration of $\mathrm{TiB}_{2}$ by aluminum. Premature failure of the cathodes resulted in termination of the project (Dorward and Payne 1983; 0orward 1983).

Because of the availability of improved materials, KACC began a new program in 1976 to develop a practical TiB 2 cathode. This program, initially funded by the U.S. Energy Research and Development Administration (ERDA) and later by DOE, encompassed the period from 1976 to 1983. The approach was to retrofit existing cells with $\mathrm{TiB}_{2}$ cathodes without major modification to the existing cells. This program is discussed in detail by Dorward and Payne (1983).

The initial (ERDA-sponsored) evaluation was carried out in a modified pilot cell consisting of two drained cathode surfaces inclined at 2 degrees from the horizontal toward a central metal well. TiB 2 tiles were temporarily bonded to a graphite substrate on the floor of a cell using carbon-based cement. Although the pilot-cell operation demonstrated the concept of using a smaller anode/cathode distance (ACD) with $\mathrm{TiB}_{2}$ cathode materials that were wetted by aluminum, severe difficulties with bonding of the tiles to the graphite occurred. The reasons for these difficulties which included tile detachment and breakage were not ascertained, but both mechanical and chemical bond failures were suspected. The few tiles that remained bonded after the test were found to be fastened by the carbonaceous ramming mix and by an aluminum carbide layer on the underside of the tiles. It was theorized that molten aluminum reacted with the carbon-based cement to form aluminum carbide, which acted as the bonding agent between the $\mathrm{TiB}_{2}$ tiles and the graphite substrate. 
A 1978 KACC patent (Payne 1978) advocates using aluminum carbide as a bonding agent to attach $\mathrm{TiB}_{2}$ plates to graphite. In Example 1 of this patent, a small 250-A reduction cell operating at $975^{\circ} \mathrm{C}$ was prepared with $\mathrm{TiB}_{2}$ plates bonded to the graphite with carbon-based cement. The bond formed slowly ovar a period of $16 \mathrm{~h}$ at which time the tiles could no longer be displaced. After 60 $h$ of operation, a cell autopsy showed that the plates were firmly bonded to the substrate by an aluminum carbide bond. However, aluminum carbide suffers at least two disadvantages as a bonding agent: 1) it dissolves readily in the bath, and 2) its electrical resistivity is high at $950^{\circ} \mathrm{C}(250 \mathrm{ohm}-\mathrm{cm})$. It las also been pointed out that the bonds fail when the cell is cooled due to cosfficient of thermal expansion (CTE) differences (Boxall, Cooke, and Hayden 1984). If aluminum carbide is an unsatisfactory bonding agent, then the usis of carbon-containing adhesives may be unsatisfactory due to the tendency to fo"n aluminum carbide. However, the patent claims that the $\mathrm{TiB}_{2}$ tiles can be bollted to the graphite underlayer by aluminum carbide (Payne 1978).

The sintered and hot pressed $\mathrm{TiB}_{2}$ tiles for the ERDA-sponsored pilot s"udy indicated the importance of using low-oxygen materials to alleviate degradayion during electrolysis (Dorward and Payne 1983). The tiles containing much higher levels of oxygen $(500 \mathrm{ppm})$ exhibited extensive breakup of the TiB 2 surface $w$ th detachment of grains and a large amount of intergranuiar porosity. These $t$ es also had extensive crack systems that traversed their entire thickness. The low-oxygen tiles revealed only minor microcracks and an 80-um penetration depth of aluminum. Several authors have discussed the influence of TiB 2 purity on intergranular penetration by molten aluminum. (a)

In the DOE funding phase of the pilot study reported by Dorward and Payne (1983), various coating processes were investigated, although none of the cuatings were subjected to bath, aluminum, or electrolysis tests. It was noted that all potential substrates matched the $\mathrm{TiB}_{2} \mathrm{CTE}$ as a primary requirement. Metal substrates mentioned in the KACC report (Dorward and Payne 1983) included

(a) Ransley 1962 and 1963; Dorward 1982 and 1983; Dorward and Payne 1983; Meyer 1983; Goodnow and Payne 1982; Zdaniewski 1985; Baumgartner 1984a and 1984 b. 
titanium, Kovar, molybdenum, tantalum, and tungsten. Nonmetallics mentioned included high-expansion graphite, titanium carbide, tungsten carbide, and $\mathrm{TiB}_{2}$.

ATso in the DOE portion of the project reported by Dorward and Payne (1983), several cathode designs were considered. The "packed-bed" cathode and "piecewise" cathode, which would have involved embedding components into the cell bottom, were considered but not tested. The planar cathode concept (as employed in the ERDA study) was discussed; and the possibility. of mechanically fastening the tiles to the cell liner was mentioned by Dorward and Payne (1983).

The replaceable cathode module (RCM) concept, consisting of assemblies of planar $\mathrm{TiB}_{2}$ tiles mounted on subassemblies that can be installed or removed without shutting down the cell, was also evaluated (Dorward and Payne 1983; Goodnow and Payne 1982). The RCMs were designed so that they were more dense than molten aluminum and thus could be set in place on the floor of a cell without attachment. The use of RCMs is desirable because 1) damaged modules can be replaced without shutting down the cell and 2) deformation of carbonbased liner materials from sodium intercalation will not impair the longevity of $\mathrm{TiB} \mathrm{B}_{2}$-based materials and bonds on the modules. In the pilot test reported by Dorward and Payne (1983), the lack of the expected energy reduction in reducing the $A C D$ was ascribed to an increasing void fraction of anode gas as the ACD was reduced.

However, modeling studies with the anode and cathode inclined at 75 degrees to the horizontal showed that orderly gas evolution in one-dimensional flow could be achieved (Dorward and Payne 1983). This finding led KACC to pursue the inclined electrode concept in pilot tests. The drained cathode assembly consisted of an "A-frame" of $\mathrm{TiB}_{2}$ materials with an anode facing each side of the frame.

The initial A-frame tests apparently involved no bonding to the cell bottom but simply mechanical contact. Problems in the initial tests were ascribed to "poor (intermittent) electrical contact between the metal pad and the base of the TiB 2 rods" (Dorward and Payne 1983). The A-frame assembly simply rested on the cell bottom. In some cases, part-to-part contact was relied on for electrical conduction; in other assemblies, an aluminum phosphate 
cement was used that underwent rapid dissolution. The cell autopsy showed severe corrosion at the bottom of the assemblies. Some of the $\mathrm{TiB}_{2}$ parts showed almost complete aluminum penetration, resulting in serious degradation in strength.

Dorward and Payne (1983) suggested the following mechanism for the sevine corrosion. If the electrical connections between the cell bottom and the base of the A-frames were degraded due to low metal level conditions, obstruction by muck or other conditions would electrically isolate the frame, and the bottorn of the frame could act as an anode. The resulting oxidation could lead to rapid dissolution of the $\mathrm{TiB}_{2}$ materials. This indicated the importance of maintaining a continuous current path to the cathode assembly. The next approach taken was to use a top-entering cathode current collector. However, difficulties were encountered protecting the current collector from chemical attack by the bath and the gaseous atmosphere above the bath.

The final report (Dorward and Payne 1985) for the period from April $19 \varepsilon \mathrm{C}$ through June 1985 covers research resulting from an amendment of the origina? DOE/KACC contract to evaluate carbon-containing $\mathrm{TiB}_{2}$ cathode material ( $\mathrm{TiBCM}$ ) that had been developed by Martin Marietta (MM) Laboratories. Commonwealth Aluminum (formally MM) was a major subcontractor to KACC during this contract phase. This proprietary carbon/ $/ \mathrm{TiB}_{2}$ composite had been tested under conventional thick aluminum pad conditions for several years (Boxa11, Cooke, and Hayden 1984).

Some of the results of the DOE/KACC research are discussed below. Two forms of TiBCM were provided by MM: 1) coatings that were troweled directly onto cathode blocks, cured, and baked, and 2) plates that were glued onto cathode blocks. Commercial cells tests consisted of coating one face of Sic plates with TiBCM, then placing the plates on edge between the sidewall and anode of a conventional Hall cell. The test sample was extensively deteriorated in regions contacting the bath.

The TiBCM materials bonded to carbon substrates were reported to be thermal shock resistant and wetted by aluminum under electrolysis conditions. These samples did not appear susceptible to physical disruption or spalling 
effects. Titanium contamination of the metal produced during short-term electrolysis tests was reported to be within acceptable limits. The wear mechanism under thin film (aluminum) conditions involved the formation and subsequent dissolution of aluminum carbide into the aluminum, leaving unattached $\mathrm{TiB}_{2}$ particles that became suspended in the aluminum. Several authors have reported wear of carbon-based materials in molten aluminum environments by way of aluminum carbide formation and dissolution (Hollingshead and Brown 1981; Dorward 1973a, 1973b; Grjotheim, Naeumann, and Oye 1977; Dewing 1969 and 1974). Additional research is needed to alleviate this wear mechanism in TiBCM materials.

The remainder of the report by Dorward and Payne (1985) is concerned with cell design and economic analysis. It is unfortunate that none of the KACC pilot facilities were configured for TiBCM testing for a small ACD and thin film operation prior to the end of the DOE contract.

\section{MARTIN MARIETTA/COMMONWEALTH ALUMINUM CORPORATION}

Martin Marietta's contribution to cathode bonding is in development of the TiBCM (Cooke et a1. 1985b; Boxa11, Cooke, and Hayden 1984; Buchta and Nagle 1983). This material consists of $\mathrm{TiB}_{2}$ powder, a carbonaceous matrix, coke particles, and, in some cases, carbon fibers. The TiBCM can be applied directly to the cathode substrate as a wet coating and then cured and carbonized. Several examples of TiBCM coating formulations are presented by Boxall and Townsend (1984), Boxall et al. (1984), Buchta and Nagle (1984) and Cooke et al. $1985 \mathrm{a}$ and $\mathrm{b}$.

A 2.5\% energy improvement was reported by Cooke et a1. (1985a) for tests performed with 20 full-scale cells that were retrofitted with TiBCM. A 5- to 7-yr lifetime was predicted. Cooke and Nagle (1985) describe lab-and planttests of TiBCM materials. The durability of the materials was strongly influenced by the amount of fiber in the mix. A conventional carbon cathode was worn away at 1 to $2 \mathrm{~cm} / \mathrm{yr}$ while the composite wear rate was reported to be an order of magnitude less. It was suggested that wear rates in the composites are controlled by $\mathrm{TiB}_{2}$ dissolution and that carbon is only attacked following localized $\mathrm{TiB}_{2}$ depletion. In Cooke and Buchta (1985), MM reports that industrial tests were performed in cells lined with the carbon/TiB ${ }_{2}$ composite 
mixtures. The refractory composite lining showed a slow and uniform erosion by dissolution, as monitored by the content of $\mathrm{Ti}$ and $\mathrm{B}$ impurities in aluminum production. Electrical energy consumption was decreased in 18-mo service tests, and the cells were operated at a lower-than-normal voltage due to tha improved cathode current distribution and cleantiness of coated cathodes. it coating service life of 5 to $7 \mathrm{yr}$ was projected.

\section{ALCOA ALUMINUM COMPANY}

Foster and Jacobs (1978 and 1979) reported an improvement in the electpolytic production of aluminum in which drained cathode surfaces were evaluated in short duration laboratory-scale experiments. These surfaces consisted o1 $\mathrm{TiB}_{2}$-based articles that were mechanically attached to graphite cell bottoms. with an interference fit rather than a cement. Various shapes of the cathock: articles were evaluated, such as solid cylinders and solid and perforated plates. Hollow cylinders open at the anode end, which filled with aluminum to act as the cathode surface, were also evaluated. Composites of $\mathrm{TiB}_{2}-\mathrm{BN}$ werk also reported to exhibit superior wear resistance during these tests. Foster and Jacobs (1978) also reported a 4000-A cell test with an array of $\mathrm{TiB}_{2}$ anc. $\mathrm{TiB}_{2}-\mathrm{BN}$ rectangular parallelepiped articles protruding from recesses in the graphite cell liner; after 65 days of continuous operation, $\mathrm{TiB}_{2}-\mathrm{BN}$ plates showed no apparent loss in dimension.

Similar reports by Das, Foster, and Hildeman (1983) explain the use of $\mathrm{TiB}_{2}$-based monoliths, which are embedded in the cell bottom and function as drained cathode surfaces. These materials are shaped as hollow or solid cylinders, and they extend either into the aluminum or bath. Coatings produced from chemical vapor deposition, slurry deposition, and plasma spraying were suggested to be useful for fabricating these cathodes. Graphite-TiB 2 composite formulations were also presented, which were reported to exhibit resistance to thermat shock.

In the drained cathode embodiments of Foster and Jacobs (1978 and 1979) and Das, Foster, and Hildeman (1983), TiB 2 -based articles are firmly embedded into carbon-based cell bottom materials; this may lead to misalignment of anode-cathode spacings or damage of the sometimes brittle $\mathrm{TiB}_{2}$-based articles, 
because of sodium intercalation and subsequent deformation of carbon-based cell bottom materials. Several authors have discussed deformation phenomena occurring in various carbon-based cell bottom materials over extended periods of time: Waddington (1963); Sorlie and Oye (1984a and b); Panebianceo and Bacchiega (1966); Dell (1967 and 1985); Dewing (1963 and 1974).

In another study by Foster, Das, and Becker (1981), the CVo coating adhesion of $\mathrm{TiB}_{2}$ on graphite was improved through control of the graphite structure to favor a higher CTE. One embodiment includes aligning the RHM coated graphite so that the graphite grain direction is parallel to the direction of current flow from anode to cathode. It was reported that the coating needs to exhibit a dense columnar structure to reduce penetration by molten a 1 umi num.

In a Battelle/Alcoa study, pipes consisting of chemical vapor-deposited $\mathrm{TiB}_{2}$ on graphite were produced and evaluated for resistance to chemical attack in a laboratory-scale Hall cell for $100 \mathrm{hr}$ (Becker and Blanks 1984). The projected lifetime of the coating was a factor of 50 shorter than that calculated by assuming uniform saturation dissolution of $\mathrm{TiB}_{2}$ in molten aluminum. Chemical attack was attributed to grain boundary penetration by aluminum.

A patent by Jacobs et al. (1983) reports the use of a bed of loosely packed objects that are placed directly on the carbon floor of a cell. Interstices between the objects accommodate molten aluminum; the bed is screeded to provide a top surface which is parallel to the bottom of the anode. The loosely packed objects, which are approximately 2 inches in size, may be preformed shapes or randomly shaped fragments. These objects may be composed of conductive or nonconductive materials; $\mathrm{TiB}_{2}-\mathrm{BN}$ composites were recommended. The bed is reported to exert a damping effect on the movement of aluminum and reduces wave amplitudes in the aluminum pad; a reduced ACD is therefore possible. It is expected that alumina concentrations in the bath must be maintained at acceptably low levels to prevent accumulation of sludge within the interstices of the packed bed.

A patent by Jarrett and Hornack (1985) discussed the use of replaceable anode/cathode modules which are suspended from anode bus bars, and are submerged into the bath and aluminum pad without making physical contact with cell 
liner or cell bottom surfaces. In several design concepts, mechanical spacars were positioned between anode and cathode surfaces to fix anode/cathode spa:ing. These design concepts use inert anodes and drained TiB 2 -based cathode:; the cathodes maintain electrical contact by being partially submerged in an aluminum pad. There are several attractive features to these designs:

1) anode/cathode spacings are fixed without being misaligned from deformation of carbonaceous cell bottoms, 2) brittle $\mathrm{TiB}_{2}$-based cathodes are not damaged from deformation of carbon cell bottoms, 3) replaceable anode/cathode modules can be serviced and retrofitted into existing commercial cells without recorl-. structing cell liners, and 4) bi-polar electrodes can be added. Additional research is needed to experimentally evaluate performance of spacer materials. and specific anode/cathode module design concepts.

REYNOLDS METALS COMPANY

A patent by Kaplan et al. (1982) discusses the use of $\mathrm{TiB}_{2}$-aluminum nitride composites bonded to graphite substrates, where the resulting tiles cre attached to carbon cell bottoms using carbon-based cement. The composite tiles were formed and the bond produced by hot pressing a mixture of $\mathrm{TiB}_{2}$ and $\mathrm{ATN}$ powders directly against a graphitic base layer in an inert atmosphere. Pricr to hot pressing, the graphitic surfaces were mechanically roughened and then air cleaned to facilitate the bonding. It is believed that the RHM coatings were bonded by sintering of powders inside of the surface imperfections of the graphite. The RHM layer may be reinforced with carbon, graphite, or silicon carbide fibers (or particles) to minimize cracking during usage. AlN additions were reported to lower the thermal expansion of $\mathrm{TiB}_{2}-\mathrm{AlN}$ composites relative to $\mathrm{TiB}_{2}$; this enabled bonding to expansion compatible graphites (Long and Foster 1959; Kaplan et al. 1982; Keihn and Keplin 1967; Skaar and Croft 1973;

Richards, Berry, and Johnston 1967 and 1968).

Test results showed that the ability to produce crack-free tiles was a function of the thermal expansion mismatch of the RHM Tayers and graphite substrates. Thermal expansion stresses varied somewhat according to hot pressing conditions and the physical dimensions of the tiles. 
Laboratory-scale reduction cell tests showed that tiles of $\mathrm{TiB}_{2}-\mathrm{A} 1 \mathrm{~N}$ hot pressed to graphite operated for periods of 200 to $700 \mathrm{~h}$ with no apparent deterioration of the hot-pressed bond or of the cemented bond to the graphite base layer (Kaplan et al. 1982). Another observation was that the graphite base layers were fully penetrated by elemental sodium and bath constituents within the first few days of testing. It is uncertain if bonds between graphite and $T i B_{2}-A T N$ are capable of withstanding long-term deformation phenomena occurring in carbon cell bottom materials (Waddington 1963; Sorlie and Oye $1984 a$ and b; Panebianceo and Bacchiega 1966; Dell 1967 and 1985; Dewing 1963 and 1974).

Additional tests were performed with a $\mathrm{TiB}_{2}-\mathrm{AlN}$ tile, which was not hot pressed to graphite; instead, the tile was cemented to the base graphite. It became detached after approximately $400 \mathrm{~h}$ of electrolysis testing (Kaplan et al. 1982). A layer of aluminum and aluminum carbide was found between the tile and the graphite, indicating that these tiles cannot be as well bonded to a carbonaceous base using carbonaceous cements as can TiB ${ }^{-A 1 N}$ hot pressed to graphite tiles.

To prevent chemical attack of graphite substrates by way of $\mathrm{Al}_{4} \mathrm{C}_{3}$ formation and subsequent dissolution, Kaplan (1982) suggested eliminating the graphite and using intermediate tiles between the RHM tiles and the cathode blocks. Intermediate tiles mentioned include $A I N, S i N, B N, T i N, Z r N, T a N$, oxynitrides, carbides such as $\mathrm{Al}_{4} \mathrm{C}_{3}, \mathrm{TiC}, \mathrm{B}_{4} \mathrm{C}, \mathrm{Zr}_{4} \mathrm{C}_{3}, \mathrm{Ta}_{2} \mathrm{C}$, and SiN-bonded SiC. The intermediate tiles were bonded to the cathode blocks by a carbonaceous cement while the RHM tiles were pinned to the intermediate tiles using RHM pins. However, it is possible that these intermediate tiles may resuit in additional voltage drops for the cell.

Richards (1983) discussed protecting the RHM/substrate bond by a solid alumina-cryolite layer between the carbonaceous cell liner and the molten aluminum pad. This stable cryolite-alumina layer was reported to prevent moiten aluminum from reaching the RHM tile-carbonaceous substrate interface, thus eliminating the cause of erosion of carbon at this interface. The mixture was formulated so that its melting point is higher than normally experienced under temperatures of aluminum production. 
The patents by Tabereaux and Willet (1984) and Stewart, Tabereaux, and Willett (1986) suggest the use of anode stops (shapes that project from the cell bottom into the bath) to prevent damage to the RHM materials by accidell;al anode movement and contact. Tabereaux (1984) and Stewart, Tabereaux, and Willett (1986) suggested the use of refractory sleeves (hollow cylinders) embedded into the carbonaceous cell bottom. The sleeves (silicon-nitridebonded silicon carbide is the preferred material) can be glued to the cell bottom with a carbonaceous cement. RHM tiles are loosely fitted into the sleeves (not bonded); these tiles act as cathodes by protruding from the sleeves into the aluminum. This approach has the advantage that the RHM tiles can be replaced while the cell is in operation. However, this design conceft may be susceptible to misalignment of anode-cathode spacings because of defcrmation of carbon-based cell bottom materials (Waddington 1963; Sorlie and Oye 1984; Panebianceo and Bacchiega 1966; Dell 1967 and 1985; Dewing 1963 and 1974).

ADDITIONAL APPLICABLE DATA

Several patents (a) were issued to Great Lakes Research Corporation for various formulations of $\mathrm{TiB}_{2}-\mathrm{graphite}$ composites $\left(\mathrm{TiB}_{2}-\mathrm{G}\right)$. Joo, Tucker, and Webb (1983a and 1983b) fabricated $\mathrm{TiB}_{2}-\mathrm{G}$ composites by heat treating mixtures of $\mathrm{TiB}_{2}$ powder and petroleum pitch materials. Joo, Tucker, and McCown (1983) mixed $\mathrm{TiO}_{2}$ and $\mathrm{B}_{2} \mathrm{O}_{3}$ in a carbonizable solution; these oxides form $\mathrm{TiB}_{2}$ during heat treating. Boron compounds were added to a $\mathrm{TiO}_{2}$-carbon composite to form $\mathrm{TiB}_{2}$ during heat treatment.

Tucker et al. (1986) reported promising results for $\mathrm{TiB}_{2}-\mathrm{G}$ materials evaluated in commercial reduction cells; these samples were wetted by aluminut, resistant to thermal shock, and in good condition after six months of cell exposure. Versatile fabricability of $\mathrm{TiB}_{2}-\mathrm{G}$ composites was also reported.

Joo et a1. (1985) also reported a method for fabricating monolithic bipolar electrodes for alumina smelting cells. The process involved brazing

(a) Joo, Tucker, and McCown 1983 and 1984; Joo, Tucker, and Webb 1983a and 1983b; Juel, Joo, and Tucker 1984. 
oxide-based cermet anodes to RHM cathode materials such as $\mathrm{TiB}_{2}$, using an Fe-Ni-Co alloy intermediate layer with a thermal expansion coefficient intermediate to the anode and cathode layers.

Molnar (1985) and Sane, Wheeler, and Kuivila (1983) proposed a loosely packed bed of RHM-coated pieces to function as a cathode on the floor of a commercial cell. These design concepts are similar to that proposed by Jacobs et a1. (1983). Sane, Wheeler, and Kuivila (1983) also reported minimal deterioration of $\mathrm{TiB}_{2}$ coatings on alumina samples which were exposed to molten aluminum for 4 to 8 weeks. They also evaluated a coated honeycomb structure during a 10-h electrolysis test; good performance was reported. The same authors recommended various coating processes including in situ formation of $\mathrm{TiB}_{2}$ films on alumina substrates immersed in a Hall-Heroult cell. These films were formed by way of aluminothermic reduction of titanium oxide and boron oxide.

Another patent from Pechiney Aluminum advocated use of a conductive screen (graphite, $C$, or $C-C$ composite coated with $T i B_{2}$ ) that floats on the aluminum pad between the aluminum and cryolite interface (Leroy and Keinborg 1984). The advantage is that the screen is not bonded or connected to the C cathodic substrate. Keller (1986) and Keinborg et al. (1985) also proposed the use of cathode members that float at the aluminum/bath interface. Possible materials include composites of $\mathrm{TiB}_{2}$-based coatings on graphite substrates. Additional research is needed to evaluate performance of such coatings, which are required to be resistant to aluminum penetration and subsequent spalling.

A Pittsburgh Plate Glass Industries patent described a halide vapor reduction process for generating high purity submicron $\mathrm{TiB}_{2}$ powder which, when hot pressed to a density of $97 \%$, operated in an aluminum reduction cell for $100 \mathrm{~h}$ with no sign of deterioration or electrolyte penetration (Hoekje 1981). Stress corrosion cracking studies by Baumgartner (1984a and 1984b) also revealed that $\mathrm{TiB}_{2}$ sintered from halide-reduced powder was exceptionally resistant to intergranular penetration by molten aluminum. 


\section{REVIEW OF ALTERNATIVE COATING TECHNIQUES}

Several $\mathrm{TiB}_{2}$ coating techniques that have not been extensively applied to Hall-Heroult cell cathodes are discussed in this section. These techniques include chemical vapor deposition (CVD), electrodeposition, plasma spraying, and miscellaneous methods.

\section{CHEMICAL VAPOR DEPOSITION}

Several authors have reported chemical vapor deposition (CVD) of $\mathrm{TiB}_{2}$ onto various substrate materials for erosion-resistant applications. Besmann and Spear (1975), Blandenet et al. (1977), Pierson, Randich, and Mattox (1979), Pierson and Mullendore (1980) and Mattox et a1. (1980) have discussed CVD methods of depositing $\mathrm{TiB}_{2}$ onto graphite substrates. Matching the therma 1 expansion of the substrates and coatings was necessary to prevent the coatings from cracking. Pierson and Mullendore (1982) presented a technique for depositing thick coatings, i.e., greater than $100 \mu \mathrm{m}$, of $\mathrm{TiB}_{2}$ onto graphite. Caputo, Lackey, and Wright (1984) deposited $\mathrm{TiB}_{2}$ onto cemented carbides and $\mathrm{Ni}$-bonded $\mathrm{TiB}_{2}$ substrates. Finch, Tennery, and Curlee (1984) also discussed deposition of $\mathrm{TiB}_{2}$ onto $\mathrm{Ni}$-bonded $\mathrm{TiB}_{2}$ substrates. Holz (1979) described a thermochemical deposition process for coating graphite or ceramics with TiB 2 . Williams (1985) discussed a glow discharge/CVD process for producing $\mathrm{TiB}_{2}$ coatings. Takahashi and Kamiya (1974) presented methods for depositing $\mathrm{TiB}_{2}$ on graphite and low carbon steel.

Becker and Blanks (1984) produced pipes of graphite that were chemica)vapor deposited with $\mathrm{TiB}_{2}$ and experimentally evaluated in a laboratory scale alumina smelter. The coatings exhibited shortened lifetimes because of grain boundary attack and subsequent crystal pull out. Additional research is needed to determine if CVD coatings of $\mathrm{TiB}_{2}$ may be feasible for Hall-Heroult cell retrofit applications. Main requirements for these applications are that the coatings remain adherent and resistant to chemical attack, and be economically produced. At present, the operating costs for the CVD process are high. Also, depending on substrate/coating thermal expansion stresses, CVD coatings of $\mathrm{TiB}_{2}$ 
may be brittle and susceptible to mechanical damage. Cracks that may develop in coatings should not result in chemical attack of substrate materials by penetrating liquids.

Gebhardt and Cree (1965) reported studies on the influence of various process variables on the structure and stoichiometry of $\mathrm{TiB}_{2}, \mathrm{HfB}_{2}$, and $\mathrm{ZrB}$ ? coatings. These authors reported preferred crystallographic orientation of coatings where the crystallites were deposited with $C$ axes parallel to substrates.

\section{ELECTRODEPOSITION}

Several authors have reported electrodeposition of $\mathrm{TiB}_{2}$ on metallic and graphite substrates. (a) The adherence varies with the thermal expansion of the substrate material. High expansion graphite and several refractory metals including titanium have CTEs that are compatible with $\mathrm{TiB}_{2}$; however, these metals are chemically reactive with flouride-based electroplating baths, and a protective base coat of copper or nickel is required (Schlain, McCawley and Smith 1976; Townsend and Boxall 1984). In a study by Townsend and Boxall (1984), it was claimed that electroplated $\mathrm{TiB}_{2}$ coatings to be used for Soderberg anode stud fastener applications are resistant to attack by cryolite and aluminum. Additional research is needed to determine the feasibility of producing Hall-Heroult cell cathode components. This research should identify whether aluminum penetrates $\mathrm{TiB}_{2}$ coatings during Hall Heroult cell usage, ar $\mathrm{d}$ if this penetration results in chemical attack of substrate materials.

\section{PLASMA SPRAYING}

Several authors have reported plasma-spraying $\mathrm{TiB}_{2}$ coatings. (b) Although this method is certainly attractive because of the rapid deposition rates

(a) Townsend and Boxall 1984; Schlain, McCawley, and Smith 1976; Flinn et a1. 1979; Flinn et al. 1981; McCawley, Schlain, and Wyche 1974; Schlain, McCawley, and Wyche 1969; Gomes, Uchida, and Wong 1975; Kellner 1975; Bracuti and Bottei 1984; Kirk, Lynch, and VanStratum 1981.

(b) Dallaire and Champagne 1984; Townsend and Boxall 1984; Fletcher 1979; Schreyer et al. 1979; Kugler and Rieger 1974; Morozumi, Kikuchi, and Kanazawa et al. 1981. 
attainable, single phase $\mathrm{TiB}_{2}$ coatings are typically porous because of difficulties melting the starting powder (Dallaire and Champagne 1984; Townsend and Boxall 1984). This porosity may lead to penetration by aluminum with subsequent deterioration of substrate materials during Hall-Heroult cell usage.

Kugler and Rieger (1974) and Dallaire and Champagne (1984) suggested means for reducing the porosity of $\mathrm{TiB}_{2}$-based plasma-sprayed coatings. Additional research is needed to verify the feasibility of these and other possible approaches for producing low-porosity cathodes that are resistant to aluminum penetration. Kugler and Rieger (1974), in a patent for flame-sprayed HallHerouit cell liners, suggested a method of plasma-spraying $\mathrm{TiB}_{2}-\mathrm{NbB}_{2}$ coatings, which enables " ... a closing of the pores for formation of a diffusion barrier." Electrolysis test performance of these coatings was not reported. Dallaire and Champagne (1984) produced $\mathrm{TiB}_{2}-\mathrm{Fe}$ coatings with reduced porosity; additional research is needed to determine if adherence is limited by chemical reactions between aluminum and the iron and iron boride phases in these coatings.

\section{MISCELLANEOUS METHODS}

Several authors have discussed diffusion saturation methods of producing boride coatings (Epik 1977; Singhal 1978; Sane, Wheeler, and Kuivila 1983). These techniques, which are sometimes referred to as boriding, involve the exposure of metallic substrates to boron-saturated media to form boride coatings; boron-saturated media may be solid (powder), liquid, or gaseous. For example, liquid phase boriding is typically performed in borax-based liquids, either with or without electrolysis, by means of reducing agents such as boron carbide or silicon carbide (Epik 1977). A review of boride diffusion saturation coating techniques emphasizing the Russian literature has been presented by Epik (1977). Sane, Wheeler, and Kuivila (1983) suggested various boriding methods for coating ceramic objects with $\mathrm{TiB}_{2}$ including the in situ formation of $\mathrm{TiB}_{2}$ films on alumina substrates immersed in aluminum in a Hall-Heroult cell.

A method of pack cementation was described by Singhal (1978) for forming extremely hard boride coatings on titanium and titanium-based alloys. The 
coatings were found to be predominantly $\mathrm{TiB}_{2}$ and to be extremely resistant to erosion. However, a pack cementation process on $\mathrm{Ti}$ resulted in a $\mathrm{TiB}_{2}$ coating which was not wetted by molten aluminum; $(a)$ the specifics of this pack cementation process were not disclosed in this report.

The Union Carbide Corporation patent by Kellar (1972) describes a hightemperature cement for joining sections of carbonaceous electric furnace electrodes. The thermosetting cement is comprised of elemental powders of boron and a transition metal, such as $\mathrm{Ti}$, mixed with a carbonizable binder. It was mentioned that bonds formed between the carbonaceous electrodes while elemental titanium and boron react during heating to form titanium diboride (Kellar 1972). It may be possible to bond $\mathrm{TiB}_{2}$-based tiles to graphite using this cement.

Hofer (1965), Gates and Hale (1980), Hale and Gates (1981), and Joo et a1. (1985) discuss methods of brazing $\mathrm{TiB}_{2}$ to metal substrates. A review of TiE? brazing patents related to Hall-Heroult cell cathode current leads is preserted by Billehaug and Dye (1980). It is uncertain whether brazing procedures can be implemented for commercial cell cathode bonding applications because of the reactivity of aluminum with most brazing alloys at cell operating temperatures.

Koizumi et al. (1984) and Suganuma et a1. (1983) discuss pressureless sintering and hot-pressing techniques that use a composite of the two materials to be bonded as a bonding layer. This approach may, in some cases, be used to introduce a compliant layer between two materials with dissimilar CTEs. This method is called "composite interlayer bonding" by the authors. It may be possible to use such methods to bond $T_{i} B_{2}$-based composites to cell liner materials. It may also be possible to use explosive bonding or high-pressuris rapid compaction methods to form similar bonded structures.

Hofer (1965) evaluated several methods of designing $\mathrm{TiB}_{2}$ mechanical joints and connections to optimize load transmitting capability for aerospace vehic'e

(a) "Qualification of Protective Layers of Titanium or Titanium Alloys as a Protection Against Liquid Aluminum," 1975. 
applications. This is the only published report we found that evaluates $\mathrm{TiB}_{2}$ mechanical fasteners; it may therefore be useful for designing attachments for Hall-Heroult cell cathodes. 


\section{RECOMMENDATIONS FOR RETROFITTING HALL CELLS}

Based on the literature review, TiB 2 -based cathode attachment methods are rated for the feasibility of retrofitting commercial Hall-Heroult cells. In the following discussion, candidate retrofitting methods are evaluated for energy-saving applications using reduced interpolar spacing and drained cathode design concepts.

Several main issues must be considered in evaluation of the stable attachment methods. When rating the techniques, the cost of materials, the cost of manufacturing components, and the ease or difficulty of retrofitting industrial cells can not be ignored. The materials used in the attachment methods must also be resistant to chemical attack in the cell environment to prevent aluminum contamination and frequent replacement of components. Furthermore, design concepts must provide stable aljgnment of reduced interpolar spacing.

An important issue affecting cathode performance is the susceptibility of some $\mathrm{TiB}_{2}$-based materials to cracking and disintegration during Hall-Heroult cell usage. $\mathrm{TiB}_{2}$ is inherently brittle; cracking of cathodes may arise from several sources such as 1) thermal shock, 2) thermal expansion differences with bonded substrate materials, 3) $\mathrm{TiB}_{2}$ thermal expansion anisotropy, 4) stresses imposed from deformation of carbon celi liners, and 5) the physical impact of tools used for cell operation. These phenomena must not lead to unplanned penetration of $\mathrm{TiB}_{2}$-based cathodes by aluminum or bath which would cause subsequent loss of coating adhesion and/or chemical attack of substrate materials. With these requirements in mind, recommendations for durable attachment methods must also include recommendations for the selection of durable $\mathrm{TiB}_{2}$-based materials to be attached (Table 1). Specific recommendations for each processing approach are presented after a brief discussion of wear-resistant materials selection.

\section{WEAR-RESISTANT MATERIALS SELECTION}

There are several $\mathrm{TiB}_{2}$-based cathode materials that are resistant to wear in molten aluminum environments. Promising recommendations may be made with 1) components sintered from high purity $\mathrm{TiB}_{2}$ powders of halide reduced origin, 
TABLE 1. TiB 2 -Based Cathode Designs

Design Concept

Attachment of $\mathrm{TiB}_{2}$-based articles to carbonaceous

cell floors:

- Cements

- TiB 2 -carbon pastes ( $T$ iBCM)

- TiB 2 -A1N hot pressed to graphite

- Mechanical fasteners

Replaceable cathode fixtures

Replaceable monopolar anode/cathode fixtures

Packed bed

Miscellaneous $\mathrm{TiB}_{2}$ coating processes:

- Chemical vapor deposition

- Electrodeposition

- Plasma spraying

- Diffusion saturation
Probability of Technical Success
Low

Medium

Medium

Medium

High

Medium

Medium

Low

Low

Medium

Medium

and 2) components sintered from lesser-purity $\mathrm{TiB}_{2}$ powders of carbothermic origin mixed with second-phase additions of AIN or $B N$. Promising recommendations may also be made with Great Lakes $\mathrm{TiB}_{2}$-graphite composites; minimal wea* was recently reported for these materials during six months of commercial Hal:Heroult cell testing (Tucker et al. 1986). Additional research is needed to characterize long-term wear mechanisms in all of the above materials. Components fabricated from halide-reduced powders have a high probability of technical success because intergranular penetration of aluminum can be minimized; single-phase $\mathrm{TiB}_{2}$ components that are fabricated from carbothermically reduced powders are susceptible to intergranular penetration by aluminum because of molten aluminum reactions with grain boundary phases containing oxygen and carbon. (a) Penetration rates as high as $1 \mathrm{~mm} / \mathrm{d}$ have been reported for lesser..

(a) Ransley 1962 and 1963; Dorward 1982 and 1983; Dorward and Payne 1983; Meyer 1983; Zdaniewski 1985; Baumgartner 1984a and 1984 b. 
purity $\mathrm{TiB}_{2}$ (Dorward 1982). Nickel bonded $\mathrm{TiB}_{2}$ has also been reported to be prone to intergranular attack (Finch and Tennery 1982).

\section{ATTACHING TiB 2 -BASED ARTICLES TO CARBONACEOUS CELL FLOORS}

Design concepts are considered which incorporate rigid attachment of $\mathrm{TiB}_{2}-$ based articles such as plates or other monolithic items to carbon cell bottom materials. However, such methods appear to be prone to ACD misalignment because of the following: 1) deformation of carbon-based cell bottom materials from thermal stresses and sodium intercalation, and 2) chemical attack of carbon-based cell bottom materials from aluminum carbide formation and subsequent dissolution. During reduced ACD operation, anode/cathode, misalignment of the ACD is expected to result in nonuniform current distribution and localized electrode wear, thereby preventing realization of maximum cost and energy savings. Furthermore, these processes may also lead to fracture and/or detachment of $T i B_{2}$-based articles. A possible solution is to develop alternative cell bottom materials; this would require major reconstruction of existing cells. To alleviate this problem, drained cathode/reduced ACD design alternatives are also considered which may be retrofitted into existing commercial cells without major reconstruction.

Cements

An alternative is to develop cements for bonding $\mathrm{TiB}_{2}$-based monolithic articles to carbon-based cell bottom materials. However, such methods would still be prone to ACD misalignment because of deformation of carbon cell bottom materials. Furthermore, cements which are capable of resisting chemical attack and cell bottom heavage do not appear to be available. Commercially available carbon-based cements are not recommended because aluminum is expected to wet the edges and undersides of $\mathrm{TiB}_{2}$-based articles, forming aluminum carbide at aluminum and carbon interfaces. Aluminum carbide is readily dissolved in a cryolite-based bath; it is also a poor electrical conductor. If interfaces between $\mathrm{TiB}_{2}$-based articles and carbon-based materials may be protected from direct contact by aluminum, the bonds are more likely to remain intact. Based 
on this information, carbon-based cements for bonding TiB 2 -based monoliths $t$.) carbon cell bottom materials have been rated with a low probability of technical success in Table 1.

$\mathrm{TiB}_{2}$ - Carbon Pastes (TiBCM)

Additional research is recommended for carbon-TiB 2 composites that can formed into tiles or directly coated as pastes onto conventional carbon cathoide block materials. TiB 2 -carbon composites produced by MM have been reported $\left.t_{1}\right)$ behave satisfactorily under thick aluminum pad conditions in commercial cell tests (Boxa11, Cooke, and Hayden 1984). However, excessive wear for these materials has been reported under thin aluminum film conditions (Dorward and Payne 1985). It is recommended that research focus on optimizing composite formulations to minimize carbon loss by way of aluminum carbide formation and subsequent dissolution. Minimization of carbon loss is especially important to alleviate spalling of $\mathrm{TiB}_{2}$ particles in composites where a continuous $\mathrm{TiB}_{2}$ matrix is absent. Research should also focus on matching the overall expans ion of paste coatings and carbon cathode block materials during Hall cell use; long duration electrolysis experiments are needed to elucidate the effects of inte"calation warpage of carbonaceous cathode blocks on bonding. If such paste coatings are successfully developed, it may be possible to develop cements that bond a variety of other $\mathrm{TiB}_{2}$-based composite materials to carbon cathode block. Based on available reports, carbon-TiB 2 pastes have been rated with i medium probability of technical success. (See Table 1.)

\section{$\mathrm{TiB}_{2}$ - AlN Hot Pressed to Graphite}

A medium probability of success has also been assigned to methods of hol: pressing $\mathrm{TiB}_{2}-\mathrm{ATN}$ coatings to graphite, with the resulting composite tiles to be cemented to carbon-based cell bottom materials (Kaplan et al. 1982). Although Kaplan et a1. (1982) reported that laboratory-scale electrolysis te!sts showed no deterioration of these coatings or bonds, it is uncertain whether cell bottom heavage may lead to ACD misalignment. In addition, it is expectiad that longer duration tests will indicate chemical attack of graphite and carloon substrates from aluminum or bath exposure. Kaplan (1982) and Richards (1983) have suggested means for protecting carbonaceous substrates from chemical attack; however, long-duration electrolysis test performance has not been 
reported. Also, $T i B_{2}-A 1 N$ composites are desirable coating materials, as they resist disintegration from intergranular penetration by aluminum. According to reports by Richards, Berry, and Johnston (1967 and 1968) and Foster and Jacobs (197B and 1979), development of $\mathrm{TiB}_{2}-\mathrm{BN}$ and $\mathrm{TiB}_{2}-\mathrm{AlN}-\mathrm{BN}$ composites is also recommended to achieve wear-resistant coatings.

\section{Mechanical Fasteners}

A variety of mechanical fastener methods mays also be devised for attaching $\mathrm{Ti}_{2}$-based monoliths to carbon cell bottom materials. These systems should be designed so that monoliths are loosely attached so as not to be damaged by cell bottom deformation. Another design consideration is that the undersides of the fastened articles should be wetted by molten aluminum to maintain uninterrupted current flow and uniform cathode current distribution. the use of a molten aluminum current path may alleviate the need for designing mechanical fasteners through which current flow is maintained; such current flow is prone to interruption through tight-fitting mechanical interfaces in a Hall-Heroult cell because the fasteners and the fastened articles are subject to chemical attack and dissolution processes. With these design considerations in mind, mechanical fastener methods have been assigned a medium probability of technical success. (See Table 1.)

\section{REPLACEABLE CATHODE FIXTURES}

Similar to methods proposed by Goodnow and Payne (1982) and Dorward and Payne (1983), a variety of replaceable cathode fixtures may be designed which are set in place, unattached, to cell bottom materials. Replaceable cathode fixtures are desirable from the standpoint of enabling evaluation and replacement of cathode components without cell shutdown or major reconstruction; a single cell may also be used to experimentally evaluate performance of a wide variety of fixture design concepts and coating processes. Furthermore, deformation of carbon cell bottom materials may occur without damaging $\mathrm{TiB}_{2}$-based components. Similar systems may be developed which use mechanical fasteners to attach replaceable modules to cell bottons; these systems may be designed so that the fixtures are loosely attached so as not to be damaged by carbon cell bottom deformation. Replaceable fixtures should also be designed so that the 
undersides are wetted by molten aluminum so as to maintain uninterrupted current flow and uniform cathode current distribution. Also, because of the various shapes which may be fabricated, prime candidate materials for replaceable cathode fixtures include Great Lakes Ti ${ }_{2}$-graphite composites. Replace.* able cathode fixtures have been assigned a high probability of technical success in Table 1.

REPLACEABLE ANODE/CATHODE FIXTURES

An alternative for fixing ACDs is to fasten electrically insulating mechanical spacers between anode and cathode surfaces, such as proposed in the patent by Jarrett and Hornack (1985). These authors designed replaceable anode/cathode fixtures that are to be suspended from anode bus bars without physically contacting cell liner or cell bottom surfaces. Inert anode and spacer materials are required. The replaceable fixtures are designed with drained $\mathrm{TiB}_{2}$-based cathodes which maintain electrical contact by being parti.. ally submerged in an aluminum pad. Such fixtures may be designed to provide maximum energy savings with reduced $A C D$ and electrolyte flow control for oxygen gas bubble removal. Furthermore, monopolar electrode design concepts appear to be easily retrofitted without major modifications into existing commercial cells. Jarrett and Hornack (1985) also suggested expanding these fixtures to include bi-polar electrodes. Experimental research is recommended for evalua-tion of monopolar design concepts and evaluation of wear resistant spacer ma1:erials. Replaceable monopolar anode/cathode fixtures have been assigned a medium probability of technical success in Table 1 . Additional development $s$ recommended for evaluation of bipolar electrode fabrication techniques.

PACKED BED CATHODES

Jacobs et al. (1983), Sane, Wheeler, and Kuivila (1983), and Molnar (1935) suggested methods of using a loosely packed bed of $\mathrm{TiB}_{2}$-based fragments or preformed shapes on the carbon floor of an existing commercial cell; interstices; between the pieces in the packed bed are filled with aluminum, damping magne1:0hydrodynamic fluid flow to enable reduced ACD operation. These design concepts can be easily retrofitted into commercial celis without major modification. 
However, screeding techniques would be necessary to maintain a flat anodefacing surface during cell operation; flatness may be upset by cell bottom deformation or the physical impact of tools or dropped anodes. Additiona? research is recommended to minimize the amount of $\mathrm{TiB}_{2}$ required for this application; porous materials or coated materials may be attractive alternatives. The effects of mucking should also be experimentally evaluated. Packed bed cathode design concepts have been assigned a medium probability of technical success in Table 1.

MISCELLANEOUS TiB, COATING PROCESSES

Following are recommendations for miscellaneous $\mathrm{TiB}_{2}$ coating processes. Chemical Vapor Deposition

$\mathrm{TiB}_{2}$ coatings produced from chemical vapor deposition are assigned a low probability of technical success in Table 1 because 1) the operating costs for the deposition process are high, and 2) the only published report that was found on the performance of such coatings in Hall-Heroult cells indicated extensive damage from $\mathrm{TiB}_{2}$ grain boundary attack (Becker and Blanks 1984). Additional research is necessary to determine if this failure mode may be alleviated using alternative substrate materials and/or deposition conditions. Also, depending on substrate/coating thermal stresses, these thin coatings may be susceptible to mechanical damage; cracks which may develop in $\mathrm{TiB}_{2}$ coatings may result in chemical attack of substrate materials by penetrating liquids during Hall cell operation.

\section{Electrodeposition}

Electrodeposited $\mathrm{TiB}_{2}$ coatings have been assigned a low probability of technical success in Table 1 mainly because the performance of these coatings in Hall-Heroult cell cathode applications has not been reported. In a study of the fabrication of Soderberg anode stud fasteners, Townsend and Boxall (1984) reported that the adherence of these coatings varies with the magnitude of substrate/coating thermal expansion stresses; it is possible that these stresses may also influence the resistance of coatings to cracking and penetration by aluminum during Hall-Heroult cell use. Electrodeposited substrate 
materials such as graphite or copper coated molybdenum are expected to be attacked by aluminum should penetration of $\mathrm{TiB}_{2}$ coatings occur. Additional research is needed to understand whether economic processes may be developed for electrodepositing $\mathrm{TiB}_{2}$-based coatings that are wear-resistant for alumini reduction cells.

Plasma Spraying

Plasma spraying has been assigned a medium probability of technical success in Table 1 mainly because of the uncertainty of producing dense $\mathrm{TiB}_{2}$ coatings with reduced porosity. Porous $\mathrm{TiB}_{2}$ coatings are typically produced, which are expected to be penetrated by aluminum or bath during Hall-Heroult cell use. Such penetration may result in chemical attack of substrate materials. Plasma sprayed coatings are certainly desirable because of the rapid deposition rates and large coating thicknesses available. However, HallHeroult cell cathode performance tests have not been reported for methods suggested for plasma-spraying dense coatings with reduced porosity (Kugler and Rieger 1974; Dallaire and Champagne 1974). Additional research is needed to evaluate these and other plasma spray methods of producing low-porosity $\mathrm{TiB}_{2}$. based coatings.

\section{Diffusion Saturation}

Diffusion saturation methods of producing $\mathrm{TiB}_{2}$ coatings have been assigned a medium probability of technical success in Table 1. Sane, Wheeler, and Kuivila (1983) reported minimal wear in Taboratory-scale Hall-Heroutt cell tests using alumina samples coated with diffusion saturated $\mathrm{TiB}_{2}$. Several other methods have been suggested for forming such coatings, as indicated by Singhal (1978) and an extensive review of $\mathrm{TiB}_{2}$ diffusion saturation methods by Epik (1977). However, only a few diffusion saturation methods have been eva uated for performance in molten aluminum environments. Sane, Wheeler, and Kuivila (1983) also suggested in-situ formation of $\mathrm{TiB}_{2}$ coatings on alumina substrates immersed in boron- and titanium-saturated aluminum in a Hall-Heroult cell. Additional research is recommended to evaluate the feasibility and performance of diffusion saturation methods. 


\section{REFERENCES}

Baumgartner, H. R. 1984a. "Mechanical Properties of Densely Sintered HighPurity Titanium Diborides in Molten Aluminum Environments." J. Am. Ceram. Soc. $67: 490$.

Baumgartner, H. R. 1984b. "Subcritical Crack Velocities in Titanium Diboride Under Simulated Hall-Heroult Cell Conditions." Am. Ceram. Soc. Bull. $63: 1172$.

Beck, T. R. 1982. "New Directions in the Aluminum Industry." In Electrochemistry in Industry - New Directions, eds. U. Landau, E. Yeager, and D. Kortan, p. 331. Plenum Press, New York.

Becker, A. J., and J. H. Blanks. 1984. "Titanium Boride (TiB2)-Coated Cathodes for Aluminum Smelting Cells." Thin Solid Films 119:241.

Besmann, T. M., and K. E. Spear. 1975. "Morphology of Chemical Vapor Deposited Titanium Diboride." J. Crystal Growth 31(1):60.

Billehaug, K., and H. A. Oye. 1980. "Inert Cathodes for Aluminum Electrolysis in Hall-Heroult Cells (I)." Aluminium 56:642.

Blandenet, G., Y. Lagarde, J. P. Morlevat, and G. Uny. 1977. "Chemical Vapor Deposition of Titanium Diboride: An X-Ray and Microanalytical Investigation of the Deposits as a Function of Coating Conditions." Proc. Electrochem. Soc. $77-5: 330$.

Boxa11, L. G., A. V. Cooke, and H. W. Hayden. 1984. "TiB 2 Cathode Material: Application in Conventional VSS Cells." J. Metals, November, p. 35.

Boxall, L. G., and D. W. Townsend. "Control of Ledge Formation in Aluminum Cel1 Operation," U.S. Patent 4,466,995. 1984.

Boxal1, L. G., W. M. Buchta, A. V. Cooke, D. C. Nagle, and D. W. Townsend. "Aluminum Cell Cathode Coating Method," U.S. Patent 4,466,996. 1984.

Bracuti, A. J., and L. A. Bottei. 1984. Evaluation of Titanium Diboride Gun Tube Coatings. ARLCD-TR-84020, SBI-AD-E401 262, 1984. Army Research and Development Center, Dover, New Jersey.

Buchta, W. M., and D. C. Nagle. "Refractory Hard Material-Carbon Fiber Cathode Coating for Aluminum Reduction Cells," European Patent (PCT) No. W0 83/00338. 1983.

Buchta, W. M., and D. C. Nagle. "Method of Making Refractory Hard Metal Containing Tiles for Aluminum Cel1 Cathodes," U.S. Patent 4,481,D52. 1984. 
Caputo, A. J., W. J. Lackey, and I. G. Wright. 1984. Chemical Vapor Deposition of Erosion-Resistant $\mathrm{TiB}_{2}$ Coatings. ORNL/TM-9042, 0ak Ridge NationaT Laboratory, Oak Ridge, Tennessee.

Cooke, A. V., L. G. Boxa11, D. C. Nagle, and W. M. Buchta. 1985a. "Carbon/ Titanium Diboride Composites for Aluminum Reduction Cells." Ext. Abstr. Priogram-Bienn. Conf. Carbon 1985, 17th, pp. 456-457.

Cooke, A. V., and D. C. Nagle. 1985. "Carbon Chemistry of Carbon/Titanium Diboride Composites." Ext. Abstr. Program-Bienn. Conf. Carbon 1985, 17th, pp. $442-443$.

Cooke, A. V., W. M. Buchta, L. G. Boxa11, and D. C. Nagle. 1985b. "Methods of Producing Titanium Diboride/Carbon Composites for Aluminum Cell Cathodes." Ext. Abstr. Program-Bienn. Conf. Carbon 1985, 17th, pp. 458-459.

Cooke, A. V., and W. M. Buchta. 1985. "Use of Titanium Diboride Cathode Ma:erial: Demonstrated Energy Conservation in VSS Cells." Light Metals, American Institute of Mining and Metallurgical Engineers, New York, pp. 545-566.

Dallaire, S., and B. Champagne. 1984. "Plasma Spray Synthesis of $\mathrm{TiB}_{2}-\mathrm{Fe}$ Coatings." Thin Solid Films 118(4):47.

Das, S. K., P. A. Foster, Jr., and G. J. Hildeman. (Alcoa) "Composite Cathode," U.S. Patent 4,396,482. 1983.

Del1, M. B. 1967. "Potlining Failures in Aluminum Electrolysis Cells." J. Metals, March, pp. 14-17.

Dell, M. B. 1985. "Potlining Failure Modes." Light Metals 1985, ed. H. D. Bohner, American Institute of Mining, Metallurgical, and Petroleurn Enginee"s, New York, pp. 957-966.

Dewing, E. W. 1963. "The Reaction of Sodium with Nongraphitic Carbon: Rea:tions 0ccurring in the Linings of Aluminum Reduction Cells." Transactions of the Metallurgical Society of AIME, 227, December, pp. 1328-1334.

Dewing, E. W. 1969. "The Solubility of Aluminum Carbide in Cryolite Melts." Transactions of the Metallurgical Society of AIME, 245, pp. 1969-2181.

Dewing, C. B. 1974. "The Chemistry of the Alumina Reduction Cel1." Can. Mzt. Quart. 13, pp. 607-618.

Dorward, R. C. 1973a. "Aluminum Carbide Formation and Removal During Electrolytic Reduction and Hot Metal Processing Operations," Light Metals 1973, ed. A. V. Clack, American Institute of Mining and Metallurgical Engineers, New York, pp. 105-118. 
Dorward, R. C. 1973b. "Reaction Between Aluminum and Graphite in the Presence of Cryolite." Metallurgical Transactions, 4, pp. 386-388.

Dorward, R. C. 1982. "Aluminum Penetration and Fracture of Titanium Diboride." J. Amer. Ceram. Soc., January, C6.

Dorward, R. C. 1983. "Energy Consumption of Aluminum Smelting Cells Containing Solid Wetted Cathodes." J.Appl. Electrochem. Vol. 13, p. 569.

Dorward, R. C., and J. R. Payne. 1983. Development of Monolithic Titanium Diboride Cathodes for Retrofit Hall Cell Applications. DOE/CS/40215-1.

Dorward, R. C., and J. R. Payne. 1985. An Evaluation of a Titanium DiborideComposite Material as Cathodes for Low Energy Alumina Reduction Cells, DOE $/ C S / 40215-2$.

Epik, A. P. 1977. "Boride Coatings." In Boron and Refractory Borides, ed. V. I. Matkovich, Springer-Verlag.

Finch, C. B., V. J. Tennery, and R. M. Curlee. "Erosion-Resistant Composite Material," UK Patent Application GB 2130251 A. 1984.

Finch, C. B., and V. J. Tennery. 1982. "Crack Formation and Swelling of $\mathrm{TiB}_{2}-\mathrm{Ni}$ Ceramics in Liquid Aluminum." J. Am. Ceram. Soc., July, C-100.

Fletcher, J. M., (British Steel Corp.-Chemicals), "Plasma Flame Spray Coated Graphite Dies," U.S. Patent 4,175,611. 1979.

Flinn, D. R., F. X. McCawley, G. R. Smith, and P. B. Needham, Jr. 1979. Electrodeposition of Erosion-Resistant Titanium Diboride Coatings. PB-293234/1, BM-RI-8332, Bureau of Mines.

Flinn, D. R., J. A. Kirk, M. J. Lynch, and B. G. Van Stratum. 1981. Wear Properties of Electrodeposited Titanium Diboride Coatings. PB81-233314, U.S. Bureau of Mines, BM-RI-8537.

Foster, P. A., Jr., and S. C. Jacobs. "Electrolytic Production of Metal," U.S. Patent $4,071,420$. 1978 .

Foster, P. A., Jr., and S. C. Jacobs. "Elektrolytische Herstellung von Metall," German Patent Offenlegungsschrift 2656579. 1979.

Foster, P. A., Jr., S. K. Das, and A. J. Becker. "Method of Producing Aluminum Using Graphite Cathode Coated with Refractory Hard Metal; Electrolysis," U.S. Patent 4,308,115. 1981.

Gates, W. G., and G. J. Hale (Bendix Corp.). "Sputter Target; Multilayer Vacuum Deposition," U.S. Patent 4,209,375. 1980. 
Gebhardt, J. J., and R. F. Cree. 1965. "Vapor-Deposited Borides of Group IV A Metals." J. Amer. Ceram. Soc. 48, pp. 262-67.

Gomes, J. M., K. Uchida, and M. M. Wong. 1975. Electrolytic Preparation of Titanium and Zirconium Diborides From Their 0xides and Mineral Concentrates. Bureau of Mines BM-RI-8053.

Goodnow, W. H., and J. R. Payne. "Aluminum Reduction Cell Electrode," U.S. Patent 4,349,427. 1982 .

Grjotheim, K., R. Naeumann, H. A. Oye. 1977. "Formation of Aluminum Carbide in the Presence of Cryolite Melts." Light Metals 1977, American Institute of Mining, Metallurgical, and Petroleum Engineers, New York, pp. 233-242.

Grjotheim, K., C. Krohn, M. Malinovsky, K. Matiasovsky, and J. Thonstad. 1982. Aluminum Electrolysis - Fundamentals of the Hall-Heroult Process." Aluminum-Verlag, Dusseldorf.

Hale, G. J., and W. G. Gates. 1981. High Temperature Bonded Titanium Diboride Sputter Target. BDX-613-2661, Bendix Corp., Kansas City, Missouri.

Hoekje, H. H. (PPG), "Submicron Titanium Boride Powder," U.S. Patent $4,282,195.1981$.

Hofer, K. E., Jr. 1965. Utilization of Refractory Nonmetallic Materials in Future Aerospace Vehicles. Part II. Study of Attachments for Brittle Components. IIRI-K259-PT-2, AFFDL-TDR-64-123-Pt-2, Lit. Research Inst., Chicago, ITlinois.

Hollingshead, E. A., and J. A. Brown. 1981. "Rate of Solution of Carbon in Molten Aluminum Under a Cryolite Melt." Light Metals, American Institute of Mining and Metallurgical Engineers, New York, p. 625.

Holzl, R. A. (Chemetals Corp.), "Deposition Method and Products; Titanium Boride Coating, hardness," U.S. Patent 4,153,483. 1979.

Jacobs, S. C., R. D. Wiltzius, J. R. Minick and P. A. Foster, Jr.

"Electrolysis Method." U.S. Patent 4,410,403. 1983.

Jarrett, N., and T. R. Hornack. "Support Member and Electrolytic Method." U.S. Patent $4,504,366.1985$.

Joo, L. A., K. W. Tucker, and F. E. McCown, Jr. "Titanium Diboride-Graphite Composites," U.S. Patent 4,376,029. 1983.

Joo, L. A., K. W. Tucker, and F. E. McCown, Jr. "Titanium Diboride-Graphite Composites," U.S. Patent 4,439,382. 1984.

Joo, L. A., K. W. Tucker, and S. D. Webb. "Controlled Atmosphere Processing of $\mathrm{TiB}_{2}$ /Carbon Composites," U.S. Patent 4,377,463. 1983a. 
Joo, L. A., K. W. Tucker, and S. D. Webb. "Sintered Refractory Hard Metals," European Patent (PCT) No. W0 83/00325. 1983b.

Joo, L. A., D. R. Secrist, J. M. Clark, K. W. Tucker, and J. R. Shaner. "Bipolar Electrode for Hall-Heroult Electrolysis," U.S. Patent 4,529,494. 1985.

Juel, L. H., L. A. Joo, and K. W. Tucker. "Composite of TiB 2 -Graphite," U.S. Patent $4,465,581$. 1984 .

Kaplan, H. I. "Alumina Reduction Ce11," U.S. Patent 4,341,611. 1982.

Kaplan, H. I., J. H. Bryce, T. J. Johnston, C. J. McMinn, J. T. Willett, and N. E. Richards. "Cathodes for Alumina Reduction Cells," U.S. Patent 4,333,813. 1982 .

Keihn, F. G., and E. J. Keplin. 1967. "High-Temperature Thermal Expansion of Certain Group IV and Group V Diborides." J. Amer. Ceram. Soc., 50, 2, pp. 81-84.

Keinborg, M., P. Varin, Y. Bertaud, and M. Leroy. "Floating Cathode Elements Based on Electrically Conductive Refractory Material for the Production of Aluminum by Electrolysis," U.S. Patent 4,532,017. 1985.

Kellar, A. A. "Electrode Joint Cement," U.S. Patent 3,657,592. 1972.

Keller, R. 1986. "Floating Cathode Parts for Aluminum Electrolysis-Materials Aspects." Extended Abstracts-Electrochemical Society Fall 1986 Meeting. San Diego, California.

Kellner, J. D. "Process for Electrodepositing Titanium Diboride from Fused Salts," U.S. Patent 3,880,729. 1975.

Kirk, D. R., J. A. Lynch, and B. G. VanStratum. 1981. Wear Properties of Electrodeposited Titanium Diboride Coatings. Bureau of Mines BM-RI-8537.

Koizumi, M., T. Okamoto, M. Shimada, K. Suganuma. 1984. "Diffusion-Reaction Bonding of Ceramics to Ceramics and to Metals under Pressure." Am. Ceram. Soc. Bu11. 63:1171.

Kugler, T., and H. W. Rieger. "Cathode for an Aluminum Fusion Electrolysis Cell and Method of Making the Same," U.S. Patent 3,856,650. 1974.

Leroy, M., and M. Keinborg, "Electrolytic Cell for Aluminum Production Having a Conductive Screen," Fr. Demande FR 2,529,580. 1984.

Long, G., and L. M. Foster. 1959. "Aluminum Nitride, A Refractory for Alumi num to $2000^{\circ} \mathrm{C} . "$ J. Amer. Ceram. Soc., 42, 2, pp. 58-59. 
Mattox, D. M., A. W. Mullendore, J. B. Whitley, and H. 0. Pierson. 1980. "Thermal Shock and Fatigue Resistant Coatings for Magnetically Confined Fusion Environments." Thin Solid Films, 73:101-107.

McCawley, F., D. Schlain, and C. Wyche. "Electrodepostition of Metallic Boride Coatings; Titanium Diboride," U.S. Patent 3,827,954. 1974.

Meyer, G. A. 1983. "Strength, Slow Crack Growth, and Penetration of Titanium Diborides in Molten Aluminum." M. SC. Thesis, Penn State University, August.

Molnar, S. (Swiss Aluminum Ltd.), "Cathode for a Fused Salt Reduction Cell," U.S. Patent 4,511,449. 1985.

Morozumi, S., M. Kikuchi, and S. Kanazawa. 1981. "Plasma Spray Coating of Low Z Ceramics on Molybdenum." J. Nucl. Mat. 103-104:279.

Panebianceo, B., and R. Bacchiega. 1966. "Deformation Phenomena in the Bottoms of Electrolytic Reduction Cells for Production of Aluminum." Alluminio, 35(3), pp. 69-78.

Payne, J. R. "Bonding of Refractory Hard Metal," U.S. Patent 4,093,524, 1978.

Pierson, H. 0., and A. W. Mullendore. 1980. "The Chemical Vapor Deposition of $\mathrm{TiB}_{2}$ from Diborane." Thin Solid Films 72(3):511.

Pierson, H. O., and A. W. Mullendore. 1982. "Thick Boride Coatings by Chemical Vapor Deposition." Thin Solid Films 95(2):99.

Pierson, H. 0., E. Randich, and D. M. Mattox. 1979. "The Chemical Vapor Deposition of $\mathrm{TiB}_{2}$ on Graphite." J. Less Common Metals, 67:381-388.

"Qualification of Protective Layers of Titanium Diboride on Titanium or Titanium Alloys as a Protection Against Liquid Aluminum. 1975. Res. Discl. $45: 136$.

Ransley, C. E. 1962. "Refractory Carbides and Borides for ATuminum Reduction Cells." 3. Metals, 14, pp. 129-135.

Ransley, C. E. 1963. "The Application of the Refractory Carbides and Borides to ATuminum Reduction Cells." Int. Symp. on the Extractive Metallurgy of Aluminum, Vol.2, ed. G. Gerard, pp. 487-506, Wiley Interscience, New York.

Richards, N. E., J. S. Berry, Jr., and T. J. Johnston. "Electrically Conductive Cermet Compositions." U.S. Patent 3,328,280. 1967.

Richards, N. E., J. S. Berry, Jr., and T. J. Johnston. "Electrically Conductive Ceramic Compositions." U.S. Patent 3,408,312. 1968.

Richards, N. E. "Alumina Reduction Cell," U.S. Patent 4,383,910. 1983. 
Sane, A. Y., D. J. Wheeler, and C. S. Kuivila (Diamond Shamrock Corp.), "Aluminum Wettable Materials," European Patent Application EP 94353 A2. 1983.

Schlain, D., F. X. McCawley, and G. R. Smith. 1976. Electrodeposition of Titanium Diboride Coatings. BUMINES-RI-8146, U.S. Bureau of Mines.

Schlain, D., F. X. MCCawley, and C. Wyche. 1969. "Electrodeposition of Titanium Diboride Coatings." J. Electrochem. Soc. 116, pp. 1227-28.

Schreyer, J. M., R. A. Hays, C. R. Schmitt, and D. Farwe11. 1979. "PlasmaSprayed Coatings for Very High Temperature Solar Adsorbers." Presented at the America Electroplaters Society Symposium on Coatings for Solar Collectors, October 1979, St. Louis, Missouri, CONF-791021-3.

Singhal, S. C. 1978. "An Erosion Resistant Coating for Titanium and Its Alloys." Thin Solid Films 53(3):375.

Skaar, E. C., and W. J. Croft. 1973. "Thermal Expansion of TiB 2 " J. Amer. Ceram. Soc., January, p. 45.

Sorlie, M., and H. A. Oye. 1984a. "Chemical Resistance of Cathode Carbon Materials During Electrolysis." Light Metals 1984, American Institute of Mining and Metallurgical Engineers, New York, Pp. 1059-1071.

Sorlie, M., and H. A. Oye. 1984b. "Deterioration of Carbon Linings in Aluminum Reduction Cells, Part II - Chemical and Physical Characterization of Cathode Carbons." Metallwissenschaft und Technik. 38:109-115.

Stewart, D. V., A. T. Tabereaux, and J. T. Willett. "Alumina Reduction Cell. U.S. Patent 4,631,121. 1986 .

Suganuma, K., T. Okamoto, M. Shimada, and M. Koizumi. July 1983. "New Method for Solid State Bonding Between Ceramics and Metals," J. Amer. Ceram. Soc. $c: 117-118$.

Tabereaux, A. T. "Alumina Reduction Cel1," U.S. Patent 4,450,054. 1984.

Tabereaux, A. T., and J. T. Willett. "Alumina Reduction Cell," U.S. Patent $4,436,598$. 1984 .

Takahashi, T., and H. Kamiya. 1974. "Chemical Vapor Deposition of Titanium Diboride." J. Crystal Growth 26(2):203.

Todd, J. B. 1981. "Energy Reduction in Hall-Heroult Cells with Conventional and Special Electrodes." J. Metals, September, p. 42.

Townsend, D. W., and L. G. Boxall. 1984. "Titanium Diboride Coatings Prepared by Plasma Spraying and Electroplating." Light Metals, American Institute of Mining and Metallurgical Engineers, New York, pp. 555-571. 
Tucker, K. W., J. R. Shaner, J. T. Gee, and L. A. Joo. 1986. Extended Abstracts, Electrochemical Society Fall 1986 Meeting, San Diego, California.

Waddington, J. 1963. "Processes Occurring in the Carbon Lining of an Aluminum Reduction Cel1." Extractive Metallurgy of Aluminum, Volume 2, G. Gerard, ed., Wiley Interscience, New York, Pp. 435-452.

Williams, L. M. 1985. "Plasma Enhanced Chemica? Vapor Deposition of Titanium Diboride Films," Appl. Phys. Lett. 46:43.

Zdaniewski, W. A. 1985. "Role of Microstructure and Intergranular Phases in Stress Corrosion of $\mathrm{TiB}_{2}$ Exposed to Liquid Aluminum." J.Am. Ceram. Soc., 68:C309. 
OISTRIBUTION

No. of

Copies

\section{OFFSITE}

30 DOE Technical Information Center

T. J. Gross

U.S. Department of Energy

Office of Industrial Programs

Forrestal Building

Washington, DC 20585

M. J. McMonigle

U.S. Department of Energy

Office of Industrial Programs

Forrestal Building

Washington, DC 20585

R. L. Sheneman

U.S. Department of Energy

Office of Industrial Programs

Forrestal Building

Washington, DC 20585

W. B. Williams

U.S. Department of Energy

Office of Industrial Programs

Forrestal Building

Washington, DC 20585

K. A. Blakely

President

Advanced Refractory

Technologies, Inc.

699 Hertel Ave.

Buffalo, NY 14207

P. Foster

Alcoa Laboratories

P.0. Box 772

New Kensington, PA 15068

W. W. Pritsky

Aluminum Association

900 19th St. N.W.

Washington, DC 20006
No. of

Copies

F. W. Baker

Ceramics Division

Aluminum Company of America

Alcoa Technical Center

Alcoa Center, PA 15069

D. H. DeYoung

Aluminum Company of America

Alcoa Technical Center

Alcoa Center, PA 15069

S. C. Jacobs

Primary Processing

Aluminum Company of America

Alcoa Technical Center

Alcoa Center, PA 15069

N. Jarrett

Aluminum Company of America

Alcoa Technical Center

Alcoa Center, PA 15069

S. P. Ray

Aluminum Company of America

Alcoa Technical Center

Alcoa Center, PA 15069

G. P. Tarcy

Aluminum Company of America

Alcoa Technical Center

Alcoa Center, PA 15069

J. D. Weyand

Aluminum Company of America

Alcoa Technical Center

Alcoa Center, PA 15069

J. Joesowicz

Material Development Laboratory

Atlantic Richfield

20717 Prairie Street

Chatsworth, CA 91311 
No. of

Copies

S. Diamond

Battelle Columbus Laboratories

$505 \mathrm{King}$ Avenue

Columbus, $O H$ 43201-2693

A. N. Patel

Battelle Columbus Laboratories

$505 \mathrm{King}$ Avenue

Columbus, $\mathrm{OH}$ 43201-2693

W. Winnard

Battelle Washington Office

2030 "M" Street N.W.

Washington, DC 20036

A. Budner

Bonneville Power Administration

P.0. Box 3621--EPC

Portland, OR 97208

G. Y. Lai

Cabot Corporation

P.0. Box 9013

Kokono, IN 46902-9013

J. W. Evans

University of California

Dept. of Mat 1. Sci, and Mineral Eng.

Berkeley, CA 94720

D. G. Howitt

College of Engineering

University of California, Davis

Davis, CA 95616

L. L. Knapp

Commonwealth Aluminum

85 John Day Dam Road

Goldendale, WA 98620

R. Engdahl

Deposits and Composites, Inc. 318 Victory Drive

Herndon, VA 22070
No. of

Copies
J. J. Leddy
Dow Chemical U.S.A.
1776 Building
Midland, MI 48640
F. W. Spillers
Dow Chemical U.S.A.
B-1210 Building
Freeport, Tx 77541
C. B. Wilson
Dow Chemical U.S.A.
Texas Operations
B-101 Building
Freeport, Tx 77541

M. H. Blenk

Du Pont

P.0. Box 787

Niagara Falls, NY 14302

V. H. Markant

ou Pont

P.0. Box $7 B 7$

Niagara Falls, NY 14302

M. Baltzell

Eastalco Aluminum Company

Alumax, Inc.

5601 Manor Woods

Frederick, MD 21701

J. V. Anderson

WCVE3

EG\&G Idaho, Inc.

Idaho Falls, ID 83415

I. L. Harry

Electric Power Research Institute

P.0. Box 10412

Palo Alto, CA 94303

T. R. Beck

Electrochemical Technology Corp.

1601 Dexter Avenue

Seatt le, WA 98109

Distr-2 
No. of

Copies

L. Gestant

Eltech Systens Corp.

625 East Street

Fairport Harbor, $\mathrm{OH} 44077$

T. Gilligan

E1tech Systems Corp.

625 East Street

Fairport Harbor, $\mathrm{OH} 44077$

R. A. Paradis

Eltech Systems Corp.

625 East Street

Fairport Harbor, $\mathrm{OH} 44077$

W. W. Liang

Gas Research Institute

8600 West Bryn Mawr Avenue

Chicago, IL 60631

W. R. Benn

Great Lakes Carbon Corp.

299 Park Avenue

New York, NY 10171

L. I. Grindstaff

Great Lakes Research Corp.

P.0. Box 1031

Elizabethon, TN 37643

L. Joo

Great Lakes Research Corp.

P.0. Box 1031

Elizabethon, TN 37643

D. R. Secrist

Great Lakes Research Corp.

P.0. Box 1031

Elizabethon, TN 37643

W. Haupin

28207 th Street Road

Lower Burrel1, PA 15068
No. of

Copies

W. L. Barham

Kaiser Aluminum and Chemical Corp.

P.0. Box 877

Pleasanton, CA 94566

J. V. Day

Mail Drop 2232

Kaiser ATuminum and Chemical Corp.

300 Lakeside Drive

0akland, CA g4643

R. D. Dorward

Kaiser Aluminum and Chemical Corp.

P.0. Box 877

Pleasanton, CA 94566

R. A. James

Kaiser Aluminum and Chemical Corp.

E2111 Hawthorne Road

Mead, WA 99021

J. R. Payne

Kaiser Aluminum and Chemical Corp.

P.0. Box 877

Pleasanton, CA 94566

T. R. Prichett

Kaiser Aluminum and Chemical Corp.

P.0. Box 877

Pleasanton, CA 94566

W. G. Lindman

KBI Division of Cabot Corp.

P.0. Box 1462

Reading, PA 19603

R. Keller

RD 3

Roundtop Road

Export, PA 15632 
No. of

Copies

W. N. Maclay

Koppers Company, Inc.

440 College Park Drive

Monroevilie, PA 15146

8. G. Epstein

A. D. Little, Inc.

600 Maryland Ave., S.W.

Washington, DC 20024

A. Moussa

A. D. Little, Inc.

20 Acorn Park

Cambridge, MA 02140

L. G. Boxall

Martin Marietta Laboratories

1450 South Rolling

Baltimore, MD 21227

A. Cooke

Martin Marietta Laboratories

1450 South Rolling

Baltimore, MD 21227

J.A.S. Green

Martin Marietta Laboratories

1450 South Rolling

Baltimore, MD 21227

R. Dethlefsen

Maxwell Laboratories

8888 Balboa Ave.

San Diego, CA 92123

J. Goodwe 11

Center for Metais Production

Mellon Institute

$4400 \mathrm{Fifth}$ Avenue

Pittsburgh, PA 15213

R. Unger

Merner Research

P.0. Box 248

Ridgewood, NJ 07451
No. of

Copies

J. F. Elliott

MIT

Room 4-138

77 Massachusetts Avenue

Cambridge, MA 02139

J. Haggerty

MIT

Building 12, Room 009

77 Massachusetts Avenue

Cambridge, MA 02139

D. R. Sadoway

MIT

Room 8-109

77 Massachusetts Avenue

Cambridge, MA 02139

M. Adkins

National Southwire Aluminum Company

P.0. Bax 500

Hawesville, KY 42348

A. B. Shah

Noranda Aluminum, Inc.

P.0. Box 70

New Madras, M0 63869

N. E. Richards

Reduction Laboratory

Reynolds Aluminum Corporation

P.0. Box 1200

Sheffield, AL 35660

R. D. Peterson

Reynolds Metals Company

P.0. Box 1200

Sheffjeld, AL 35660

D. Strahan

Reynolds Metals Company

P.0. Box 27003

Richmond, VA 23261 
No. of

\section{Copies}

C. J. McMinn

Extractive Metallurgical

Department

Reynolds Metals Company

P.0. Box 1200

Sheffield, AL 35660

C. H. Doerr

The Stackpole Corporation

Cermag Division

201 Stackpole Street

St. Marys, PA 15857

S. H. Jan

Tennessee Valley Authority

1850 Commerce Union Bank B1dg.

Chattanooga, TN 37401

J. A. Barclay

U.S. Bureau of Mines

2401 "E" Street N.W.

Washington, DC 20241

G. R. Hyde

U.S. Bureau of Mines

2401 "E" Street N.W.

Washington, DC 20241

K. Krupinski

Mail Stop 57

U.S. Steel Technical Center

1 Technical Center Drive

Monroeville, PA 15146

J. U. Brown, Jr.

Materials Engineering

Virginia Polytechnic Institute

Blacksburg, VA 24061

Doug Auburg

Bonneville Power Administration

P.0. Box 3621, PDX 97208

Portland, OR 97208

Syd Berwagan

Bonneville Power Administration

P.0. Box $3621 \mathrm{~K}$

Portland, OR 97208
No. of

Copies

\author{
John Bracher \\ Kaiser Aluminum and Chemical \\ Corp. \\ 825 N.E. Multnomah St., \\ Suite 960 \\ Portland, OR 97232-2150 \\ Norm Clark \\ Bonneville Power Administration- \\ Industrial Conservation \\ P.0. Box 3621 \\ Portiand, OR 97208 \\ Toin Foley \\ Northwest Power Planning \\ Council \\ 850 S.W. Broadway, Suite 1100 \\ Portland, OR 97205 \\ Moustafa Karmous \\ Oregon State Department of \\ Energy \\ 625 Marion Street, N.E. \\ Salem, OR 97310 \\ Steve Loftness \\ Washington State Energy Office \\ $400 \mathrm{E}$. Union \\ 01 ympia, WA 98504 \\ R. C. Rohwedder \\ 3028 Ohio Street \\ Longriew, WA \\ Noel Shelton \\ Intalco \\ 1300 S.W. 5th, Suite 3508 \\ Portland, OR 97201 \\ Arnold Vinnard \\ Bonneville Power Administration \\ (KWI) \\ P.0. Box 3621 \\ Portland, OR 97208
}


No. of

Copies

Tom von Müller-KWI

Bonneville Power Administration

P.0. Box 3621

Portland, OR 97208

Alton $T$. Tabereaux

Reynolds Metals Company

P. 0. Box 1200

Sheffield, AL 35660

Howard Wayne Hayden, Jr.

1419 East 21st Street

The Dalles, OR 97058

Joseph J. Ritter

Ceramics Division

National Bureau of Standards

Gaithersburg, MD 20899

Theodore Besmann

Metals and Ceramics Division

Oak Ridge National Laboratory

Oak Ridge, TN 37831

H. Robert Baumgartner

Alcoa Laboratories

Ceramics Division

Alcoa Center, PA 15069

Kenneth $W$. Tucker

Great Lakes Research Corp.

P. 0. Box 1031

Elizabethton, TN 37643

G. $S \operatorname{cott}$

424 Adrian Ct.

Claremont, CA 91711

FORE IGN

D. Brodie

Comalco Ltd.

55 Collins St.

Melbourne, AUSTRALIA
No. of

Copies

T. Kjar

Comalco Ltd.

55 Collins St.

Melbourne, AUSTRALIA

E. W. Dewing

Alcan International

P.0. Box 8400

Kingston, Dntario

CANAOA K7L $4 Z 4$

T. J. Hudson

Alcan International

2001 rue University

C.P. 6090

Mont real, Quebec

CANADA H3C $3 \mathrm{H} 2$

D. N. MacMillan

Alcan International

C.P. 1250

Jonquieve, Quebec

CANADA G7S 4 K8

T. Rawlings

Alcan International Limited

Engineering Division

C.P. 6090

Montreal, Quebec

CANADA, $\mathrm{H} 3 \mathrm{C} 3 \mathrm{H} 2$

J. H. Reimers

Jan $H$. Reimers and Associates

Inc.

221 Lakeshore Road East

Dakville, Ontario

CANADA L6J $1 \mathrm{H} 7$

K. Matrasovsky

Institute for Inorganic Chemistry

Centre for Chemical Research

Slovak Academy of Sciences

84236 Bratislava, CZECHOSLOVAKIA 
No. of

Copies

A. Oye

Institute of Inorganic Chemistry

Norwegian Institute of Technology

University of Trondheim

$\mathrm{N}-7034$ Trondheim-NTH, NORWAY

$\mathrm{J}$. Thonstad

Laboratories of Industrial

Electrochemistry

Norwegian Institute of

Technology

University of Trondheim

$\mathrm{N}-7034$ Trondheim-NTH, NORWAY

K. 0 . Vee

ASV

Ardal Verk

$\mathrm{N}-5875$ Ardalstargen, NORWAY
No. of

Copies

ONSITE

2 DOE Richland Operations Office

J. J. Sutey/D. R. Segna

M. J. Plahnta

39 Pacific Northwest Laboratory

K. E. Bailey

M. Clement

N. C. Davis

J. R. Divine

G. Exarhos

T. L. Gilbride

P. E. Hart (5)

O. H. Koski

S. C. Marschman

G. L. McVay

N. L. Moore

C. H. Schilling (15)

C. F. Windisch

B. J. Wrona

Publishing Coordination (2)

Technical Report Files (5) 
